\title{
Hypohidrotic Ectodermal Dysplasia: Breastfeeding Complications Due to Impaired Breast Development
}

\author{
Hypohidrotische ektodermale Dysplasie: Stillschwierigkeiten \\ aufgrund gestörter Brustentwicklung
}

\author{
Authors \\ Mandy Wahlbuhl-Becker ${ }^{1}$, Florian Faschingbauer ${ }^{2}$, \\ Matthias W. Beckmann ${ }^{2}$, Holm Schneider ${ }^{1}$

\begin{abstract}
Affiliations
1 Universitätsklinikum Erlangen, Kinder- und Jugendklinik, Kompetenzzentrum für Ektodermale Dysplasien, Erlangen, Germany

2 Universitätsklinikum Erlangen, Frauenklinik, Erlangen, Germany
\end{abstract}

Key words

hypohidrotic ectodermal dysplasia, mammary gland, breast, areola, glands of Montgomery, breastfeeding routine

Schlüsselwörter

hypohidrotische ektodermale Dysplasie, Brustdrüse (Mamma), Areola, Montgomery-Drüsen, Stillverhalten

$$
\begin{array}{ll}
\text { received } & 11.8 .2016 \\
\text { revised } & 15.12 .2016 \\
\text { accepted } & 1.1 .2017
\end{array}
$$

\section{Bibliography}

DOI http://dx.doi.org/10.1055/s-0043-100106

Geburtsh Frauenheilk 2017; 77: 377-382 @ Georg Thieme Verlag KG Stuttgart · New York | ISSN 0016-5751

\section{Correspondence}

Dr. Mandy Wahlbuhl-Becker

Kinder- und Jugendklinik, Abt. Molekulare Pädiatrie,

Universitätsklinikum Erlangen

Loschgestraße 15, 91054 Erlangen, Germany

mandy.wahlbuhl-becker@uk-erlangen.de

Deutsche Version unter:

http://dx.doi.org/10.1055/s-0043-100106

\section{ABSTRACT}

Background X-linked hypohidrotic ectodermal dysplasia (XLHED), the most common form of ectodermal dysplasia, is caused by mutations in the gene EDA. While only affected men develop the full-blown clinical picture, females who are heterozygous for an EDA mutation often also show symptoms such as hypodontia, hypotrichosis and hypohidrosis. These women may also suffer from malformations of the mammary gland which represent not just a cosmetic problem but can limit their breastfeeding capability. This paper summarizes the findings of the first systematic study on the impact of hypohidrotic ectodermal dysplasia on breastfeeding.

Patients Thirty-eight adult female members of the German-SwissAustrian ectodermal dysplasia patient support group participated in a structured interview; most of them also agreed to a photodocumentation of their mammary region. Thirty-one women carried mutations in
EDA (Group A) and seven were affected by other forms of hypohidrotic ectodermal dysplasia (Group B).

Results $39 \%$ of the women of Group A reported that their breasts were of different size or entirely absent on one side. In Group B, 86\% of the women reported differently sized or even absent breasts; two of these women lacked both breasts entirely. Most women described their nipples as exceptionally flat. $10 \%$ of the women of Group A had more than two nipples. The high percentage of deviations from the norm was confirmed in the photodocumentation. Both groups had few or no sebaceous glands of Montgomery in the areolar region. Around $80 \%$ of interviewed women had children and had attempted to breastfeed their first child. $67 \%$ of the mothers in Group A had had difficulty in breastfeeding their infants and generally attributed this difficulty to their flat nipples. All of the mothers in Group B reported difficulties in breastfeeding; $60 \%$ had not been able to breastfeed their first child.

Conclusion Mothers with hypohidrotic ectodermal dysplasia very often have difficulty in breastfeeding because of their impaired breast development. This causal relationship needs to be taken into account in lactation counseling.

\section{ZUSAMMENFASSUNG}

Hintergrund Obwohl Mutationen im X-chromosomalen Gen EDA, die der häufigsten Form ektodermaler Dysplasie (XLHED) zugrunde liegen, nur bei betroffenen Männern zum Vollbild dieser Krankheit führen, weisen auch heterozygote Mutationsträgerinnen oft Symptome wie Hypodontie, Hypotrichose und Hypohidrose auf. Außerdem ist eine Fehlentwicklung der Brustdrüsen möglich, die nicht nur ein kosmetisches Problem darstellt, sondern auch die Stillfähigkeit limitieren kann. Hierzu wurden erstmals systematisch Daten erhoben.

Patienten 38 erwachsene weibliche Mitglieder der Selbsthilfegruppe Ektodermale Dysplasie e. V. standen für ein strukturiertes Interview und meist auch für eine Fotodokumentation ihrer Brustregion zur Verfügung. Darunter waren 31 Trägerinnen von Mutationen im Gen EDA (Gruppe A) sowie 7 Frauen mit anderen Formen der hypohidrotischen ektodermalen Dysplasie (Gruppe B).

Ergebnisse 39\% der Frauen aus Gruppe A gaben an, ihre Mammae seien unterschiedlich groß bzw. auf einer Seite gar nicht vorhanden. In Gruppe B berichteten dies sogar 86\%, wobei 2 Frauen beide Brustanlagen völlig fehlten. Die meisten beschrieben ihre Brustwarzen als auffällig flach. 10\% der Frauen aus Gruppe A hatten mehr als 2 Mamillen. Der hohe Anteil an Normabweichungen wurde anhand der Fotodokumentationen bestätigt. Zudem waren in beiden Gruppen kaum Montgomery-Drüsen im Warzenhof zu finden. Ca. $80 \%$ der Befragten hatten Kinder und schon das erste zu stillen versucht. $67 \%$ der Mütter aus Gruppe A erlebten dabei Stillschwierigkeiten, die meist auf zu flache Brustwarzen zurückgeführt wurden. Alle Mütter aus Gruppe B berichteten über Stillprobleme; $60 \%$ seien nicht imstande gewesen, ihr 1. Kind zu stillen. 
Schlussfolgerung Aufgrund gestörter Brustentwicklung kommt es bei Müttern mit hypohidrotischer ektodermaler Dysplasie ungewöhnlich oft zu Stillschwierigkeiten. Dieser kausale Zusammenhang sollte bei der Laktationsberatung berücksichtigt werden.

\section{Introduction}

Skin appendages, such as hair, nails, sweat glands, sebaceous glands and mammary glands, are complex structures which mainly originate from the embryonic ectoderm. Malformations of two or more different skin appendages are classified as ectodermal dysplasias [1]. The most common condition is hypohidrotic ectodermal dysplasia (HED). Most cases are inherited in an X-linked pattern (XLHED or Christ-Siemens-Touraine syndrome; \#MIM 305100); it is a rare condition with an incidence of approximately $1: 30000$. XLHED is caused by mutations in the gene EDA (localization: Xq12-q13.1; \#MIM 300451) which encodes ectodysplasin A, a protein from the family of tumor necrosis factor- $\alpha$ ligands. Mutations of the genes EDAR (localization: 2q11-q13; \#MIM 604095) or EDARADD (localization: 1q42-q43; \#MIM 606603) which code for the ectodysplasin A1 receptor and the associated adapter protein, respectively, produce a clinical picture similar to that of XLHED and are inherited either in an autosomal recessive or autosomal dominant pattern [2]. The cardinal symptom is a reduced or missing ability to sweat (hypohidrosis or anhidrosis).

Pathogenic changes of the X-chromosomal gene EDA lead to full-blown disease manifestations only in men, but heterozygous female carriers of such mutations often present with hypohidrosis of varying severity, sparse scalp hair (hypotrichosis) and missing teeth (hypodontia) as well as characteristic dental anomalies. Male XLHED patients may also show a lack of nipples or supernumerary nipples [3]; there are, as yet, no systematic investigations of affected women. Hypothelia in women is not just a cosmetic problem but can also result in difficulties when trying to breastfeed. Several isolated cases have been published, in which developmental disorders of the female breast were caused by mutations in one of the genes of the ectodysplasin A signaling pathway [4-8].

A reduced breastfeeding capability due to anatomical or functional reasons must be considered a disease of clinical significance. Breast milk contains a mixture of nutrients tailored to the infant's needs, supplies the infant with important antibodies, and is the optimal nutrition for healthy babies. Breastfeeding offers indisputable health benefits to the infant and its mother [9]. It is therefore recommended that infants born at term should be exclusively breastfed until the beginning of the 5th month post partum. Infants should still be breastfed even when starting to supplement breast milk with other foods [10].

Disturbances of mammary gland function in women with HED are primarily the result of developmental disorders during the embryonic phase. Studies in HED mouse models have highlighted the important role of ectodysplasin A in embryonic mammary gland development [11]. The ectodysplasin signaling pathway is a key player in the early development of many vertebrates and is con- sidered a strongly conserved evolutionary feature [12]. Placodes arising from ectodermal tissue [13] develop during the early embryonic stages; they grow into the underlying mesenchyme where they form gland buds. This process is directed by a complex interaction between activating and inhibitory signals which, in the case of the ectodysplasin pathway, finally lead to the activation of NFkB. Disorders of the signaling pathway result in impaired organ development [14], giving rise to malformations or aplasia of certain organs such as the mammary glands. This study is the first to systematically collect data of female HED patients in order to assess the relevance of information obtained from the animal studies for the breastfeeding capability of affected individuals.

\section{Patients and Methods}

\section{Study design}

At the annual meeting of the German-Swiss-Austrian ectodermal dysplasia patient support group all interested female members of the group aged between 15 and 59 years were interviewed. Interviews were carried out after all participants had given their written informed consent. Questions took the form of a structured interview in which the women were asked about the maturation of their mammary glands during puberty and about the appearance of their breasts including the nipples and areolar area. If any of the women had already given birth, they were also asked about their ability to breastfeed and their experience of breastfeeding. In addition, the breast area was documented photographically; 12 of 38 participants did not consent to being photographed. To ensure the anonymity of the subjects during data collection and creation of the photographic documents, the interview and the photography were carried out by a single researcher who had not taken part in either the previous general information event nor in the patient briefing and who did not know any of the women personally. Data were anonymized prior to storage and processing.

Each questionnaire completed during the interview contained specific questions about breast development (age at the start of development, course of development, difference in sizes, characteristics of nipples), pregnancy (number of pregnancies, maternal age, outcome) and 10 questions on breastfeeding for every child born (decision to breastfeed, duration of exclusive or partial breastfeeding, self-assessment of ability to breastfeed, reasons for difficulty in breastfeeding, weight development of the breastfed infant, differences in breastfeeding between the first child and later children).

\section{Patients}

Of the 38 women who participated in the study 31 were heterozygous carriers of an EDA mutation, some of them with clinically evident XLHED; these women were pooled into Group A. Seven 
women with autosomal recessive or autosomal dominant forms of HED made up Group B.

\section{Statistical analysis}

Data are given as mean values with standard deviations. Groups A and $B$ were compared with one another and with available data from the normal population. Statistical analysis was done using the Mann-Whitney U-test. Unless stated otherwise, the level of significance was set to $5 \%$.

\section{Results}

\section{Characteristics of both patient groups}

The mean age of the women of Group A was $38.7 \pm 11.4$ years, while the women of Group B had a mean age of $33 \pm 8.1$ years. Average age at menarche in both groups was $12 \pm 1.2$ years, which corresponds to the normal age at menarche in Central Europe [15]. $77.8 \%$ of the interviewed women had given birth; $85 \%$ of them had two or more children. Mean maternal age at the birth of the first child was $29 \pm 5.2$ years, which corresponds to the mean maternal age for primiparae in Germany [16].

\section{Breast size and maturation during puberty}

$90 \%$ of the women of Group A and $43 \%$ of the women of Group B had initially considered their breast development during puberty as normal. The majority of women in Group B, however, retrospectively reported an annoying difference in size of their breasts already in puberty. At the time of the interview $39 \%$ of the women of Group A stated that their breasts were of unequal size (anisomastia) or entirely absent on one side, while $86 \%$ of the women of Group B deplored the underdevelopment of their breast on one or both sides ( $\mathbf{F i g} \mathbf{1} \mathbf{a}$ and $\mathbf{b}$ ). One case in Group A and 3 cases in Group B had unilateral or bilateral amastia, a complete absence of breast tissue, areola and nipple ( Fig. 1 c).

\section{Nipple}

$58 \%$ of the women of Group A and 57\% of the women of Group B described their nipples as exceptionally flat. $8 \%$ of the women had a nipple malformation which took the form of bilateral inverted (retracted or invaginated) nipples ( $\bullet$ Fig. $\mathbf{1} \mathbf{b}$ ); the incidence was slightly higher in Group B ( $\bullet$ Table 1) and significantly higher than in healthy women, of whom only $1 \%$ present with true inverted nipples [17]. The unilateral or bilateral presence of more than
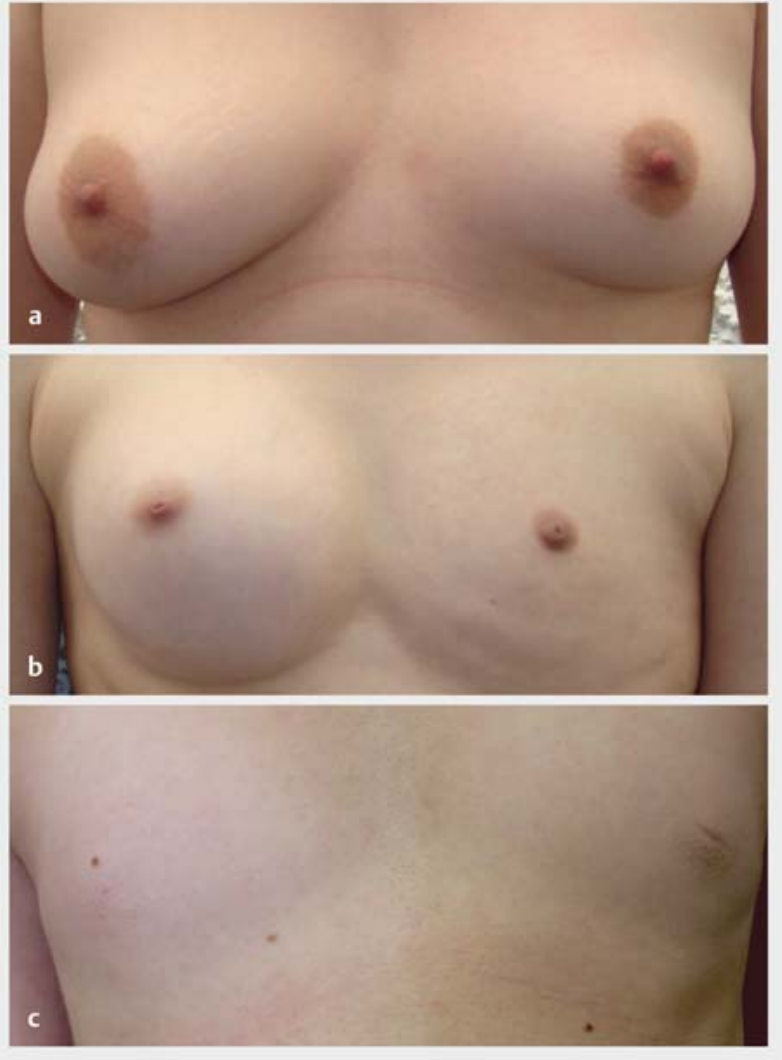

- Fig. 1 Selected images from the photodocumentation of the breast region of female HED patients. a Slight difference in the size of the breasts of one patient in Group A; b Major difference in breast sizes in a patient from the same group; c Complete absence of breasts in a patient from Group B.

two nipples (polythelia; • Fig. 2) was also uncommonly frequent with $10 \%$, but was reported only in Group A ( $\bullet$ Table 1 ).

\section{Glands of Montgomery}

Only one of 26 women in Group A and no woman in Group B had the normal number of 10-15 glands of Montgomery [18] on the photodocumentation of the areola ( $\bullet$ Table 1$)$. The mean number of glands of Montgomery did not differ significantly between the two groups (3.9 \pm 6 in Group A vs. $1.4 \pm 3.1$ in Group B, $p=0.26$ ).

- Table 1 Characteristics of the nipple and areola.

\begin{tabular}{|l|c|l|}
\hline & Group A & Group B \\
\hline Exceptionally flat nipples & $18 / 31(58 \%)$ & $4 / 7(57 \%)$ \\
\hline Inverted nipples & $2 / 31(6.5 \%)$ & $2 / 7(28 \%)$ \\
\hline Polythelia & $4 / 31(13 \%)$ & $0 / 7(0 \%)$ \\
\hline Fewer than 10 glands of Montgomery per areola & $25 / 26(96 \%)$ & $5 / 5(100 \%)$ \\
\hline No glands of Montgomery & $11 / 26(42 \%)$ & $4 / 5(80 \%)$ \\
\hline
\end{tabular}



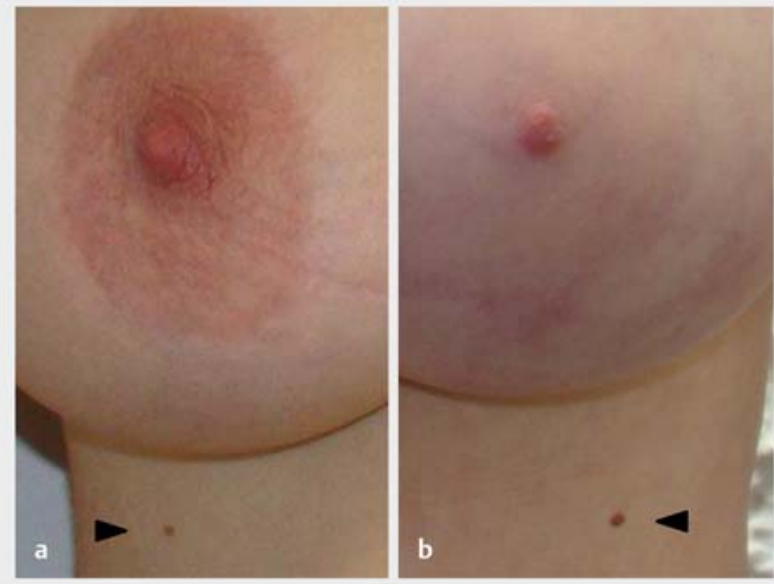

- Fig. 2 Polythelia in HED patients. Supernumerary nipples are indicated by black arrows.

Often no glands of Montgomery were visible in the areolar areas ( $\vee$ Fig. 3 b to $\mathbf{d}$ ).

\section{Ability to breastfeed and experience of breastfeeding}

Almost all of the interviewed mothers had seriously attempted to breastfeed their first child, although $67 \%$ of the mothers of Group A had experienced difficulties in breastfeeding, which they mostly ascribed to having too flat nipples. $19 \%$ were not able to breastfeed at all. Every mother in Group B reported difficulties in breastfeeding; $60 \%$ had not been able to breastfeed their first child. The main reasons given by the women were too flat nipples (56\%) or too little milk (19\%). $24 \%$ of all mothers were only able to breastfeed with the help of breastfeeding aids (e.g. nipple shields).

Notably, women experienced significantly less difficulties in breastfeeding subsequent children. In answer to the question: "Was there a difference between breastfeeding your first child and breastfeeding any subsequent child?" $60 \%$ of the mothers responded with "Yes". More than $90 \%$ of these mothers experienced breastfeeding their first child as more difficult and reported that the milk flow was higher after the second pregnancy. Moreover, they also had the impression that their nipples and areolar areas had increased in size.

\section{Discussion}

Disorders of breast development are of great psychological importance during puberty and adolescence. The ensuing limitation on breastfeeding also deserves attention. Among the malformations with increased incidence in women with HED, unilateral or bilateral amastia is certainly the most medically relevant problem, given that it affected $43 \%$ of investigated women with non $X$ chromosomal HED (Group B) in our study. This indicates that mutations of the gene EDAR or EDARADD may result in more serious disturbances of breast development than EDA mutations, which is consistent with published case reports [6-8]. Further molecular

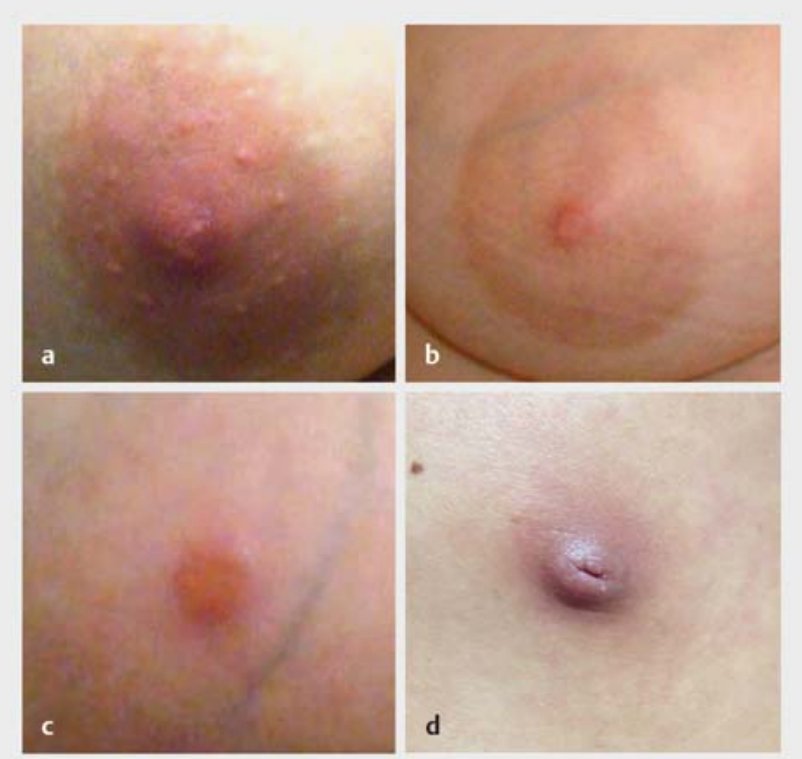

- Fig. 3 Abnormalities of nipple and areola. a Normal nipple of a 39-year-old woman; b Characteristic flat nipple of a 41-year-old patient of Group A with no glands of Montgomery in the areola; c Barely protracted nipple and absent glands of Montgomery in a patient of Group B (27 years old); $\mathbf{d}$ Inverted nipple without discernible areola in a 35-year-old patient of Group B.

research will be necessary to uncover the reasons for this difference.

The above-average percentage of cases with breast asymmetry or polythelia among women with HED may only be of cosmetic importance. In healthy women, the incidence of polythelia is between 1 and $5 \%[19,20]$. Surgical removal is not necessary in most cases as the supernumerary nipples are rarely perceived as irritating. A noticeable difference in breast size is, however, more likely to trigger a wish for plastic surgery.

Highly interesting is the finding that the numbers of glands of Montgomery in the areolar areas of women with HED are significantly reduced, which is documented here for the first time. Glands of Montgomery are sebaceous glands; their secretions protect both nipple and areola and help create an airlock between mouth and nipple during breastfeeding while the infant is sucking. The pheromones of these glands help to guide the infant to find the nipple [21]. An abundance of glands of Montgomery is associated with earlier onset of lactation and more frequent intake of breastmilk by the infant [22]. It can therefore be assumed that the reported difficulties in breastfeeding are also associated with a lack of these glands.

The often flat nipples and malformations such as inverted nipples found in women with HED also contribute to the increased problems with breastfeeding. In a survey of healthy mothers, around $60 \%$ of the women reported having had problems with breastfeeding at one point. The main reason for the problems cited by these women were wounded nipples (mentioned by $49 \%$ of the women), while flat or inverted nipples were only present in $8 \%$ of cases [23]. Given the above-mentioned findings, 
in women experiencing difficulties in breastfeeding which are not caused by visible abnormalities of the nipple shape, we would generally recommend examining the glands of Montgomery and looking for other symptoms of HED. If a diagnosis of HED is made, this must have implications for lactation counseling, for example by recommending special salves or nipple shields.

The limitations of this study include the relatively low number of subjects owing to the rarity of HED, particularly in Group B, and the unfortunately incomplete photodocumentation of subjects due to the missing consent by some participants. The lack of individual photographs, however, does not affect the finding of significantly decreased numbers of glands of Montgomery in both groups.

A further limitation could be the fact that the majority of data were collected retrospectively, making it impossible to rule out gaps or imprecise recollections. Nevertheless, the subjective perception that breastfeeding improved with the second child appears plausible to us. The most likely reason for this is that the mammary gland reacts more quickly to hormonal stimuli in subsequent pregnancies. This may be due to changes in methylation patterns of certain DNA sections which are responsible for pregnancy-related remodeling of the breast. Such changes persist after the first pregnancy and period of lactation, promoting faster reactions to hormones in subsequent pregnancies [24]. The mother's prior experience of breastfeeding probably also plays a role.

As shown in a parallel study of infants and toddlers with HED, affected children who were exclusively breastfed had a normal weight gain. If there were breastfeeding problems, the period of breastfeeding was usually too short to make valid statements on weight gain.

Specific characteristics of neonates with HED, e.g. mandibular hypoplasia, could also be a reason for difficulties in breastfeeding. As affected infants are generally still able to suck normally, these characteristics appear to be of secondary importance.

Breastfeeding and the associated difficulties are some of the most important topics discussed by affected women in the German-Swiss-Austrian ectodermal dysplasia patient support group and similar support groups in other countries. The knowledge that heterozygous carriers of EDA mutations have more problems with breastfeeding than healthy mothers and that these are problems for which they cannot be held responsible should take the psychological pressure off affected women after giving birth. This aspect was felt to be very important by the female members of the above-mentioned support group and should be taken into account in maternity hospitals, in order to "promote optimal treatment in the sense of encouraging breastfeeding while having regard to the welfare of both the mother and the infant" [25]. Prior to pregnancy, inverted nipple surgery, a relatively minor procedure, could be carried out in some cases and nipple and areola could be modified such that the patient's ability to breastfeed would no longer be limited. This procedure resulted in a normalization of most patients' breastfeeding capability [26, 27].

For XLHED, by far the most common form of HED, a causative treatment is currently being evaluated in clinical trials in male patients (www.clinicaltrials.gov NCT01775462 and NCT01992289). New information on developmental disorders of the mammary gland could be taken as an opportunity to open these studies to affected female individuals.

\section{Conclusion}

As a consequence of breast development disorders mothers with hypohidrotic ectodermal dysplasia have unusually high rates of difficulty in breastfeeding. This needs to be taken into account during lactation counseling and could be an argument for expanding current therapeutic trials with recombinant ectodysplasin A to include also female patients.

\section{Acknowledgement}

We would like to thank all of the women who participated in this study and the Selbsthilfegruppe Ektodermale Dysplasie e. V. for its support.

\section{Conflict of Interest}

The authors declare that they have no conflicts of interest.

References

[1] Pinheiro M, Freire-Maia N. Ectodermal dysplasias: a clinical classification and a causal review. Am J Med Genet 1994; 532: 153-162

[2] Cluzeau C, Hadj-Rabia S, Jambou M et al. Only four genes (EDA1, EDAR, EDARADD, and WNT10A) account for $90 \%$ of hypohidrotic/anhidrotic ectodermal dysplasia cases. Hum Mutat 2011; 32: 70-72

[3] Clarke A, Phillips DI, Brown R et al. Clinical aspects of X-linked hypohidrotic ectodermal dysplasia. Arch Dis Child 1987; 62: 989-996

[4] Heckmann U. Die kongenitale bilaterale Amastie bei Mutter und Tochter; Kasuistische Mitteilung. Geburtsh Frauenheilk 1982; 42: 318-320

[5] Al Marzouqi F, Michot C, Dos Santos S et al. Bilateral amastia in a female with X-linked hypohidrotic ectodermal dysplasia. $\mathrm{Br}$ J Dermatol 2014; 171: 671-673

[6] Wohlfart S, Söder S, Smahi A et al. A novel missense mutation in the gene EDARADD associated with an unusual phenotype of hypohidrotic ectodermal dysplasia. Am J Med Genet A 2015; 170A: 249-253

[7] Haghighi A, Nikuei P, Haghighi-Kakhki H et al. Whole-exome sequencing identifies a novel missense mutation in EDAR causing autosomal recessive hypohidrotic ectodermal dysplasia with bilateral amastia and palmoplantar hyperkeratosis. Br J Dermatol 2013; 168: 1353-1356

[8] Mégarbané $\mathrm{H}$, Cluzeau C, Bodemer C et al. Unusual presentation of a severe autosomal recessive anhydrotic ectodermal dysplasia with a novel mutation in the EDAR gene. Am J Med Genet A 2008; 146A: 2657-2662

[9] Ip S, Chung M, Raman $G$ et al. Breastfeeding and maternal and infant health outcomes in developed countries. Evid Rep Technol Assess (Full Rep) 2007; 153: 1-186

[10] Koletzko B, Bauer CP, Brönstrup A et al. Säuglingsernährung und Ernährung der stillenden Mutter. Aktualisierte Handlungsempfehlungen des Netzwerks Gesund ins Leben - Netzwerk Junge Familie, ein Projekt von IN FORM. Monatsschr Kinderheilkd 2013; 161: 237-246

[11] Lindfors PH, Voutilainen M, Mikkola ML. Ectodysplasin/NF-kB signaling in embryonic mammary gland development. J Mammary Gland Biol Neoplasia 2013; 18: 165-169 
[12] Pantalacci S, Chaumot A, Benoît G et al. Conserved features and evolutionary shifts of the EDA signaling pathway involved in vertebrate skin appendage development. Mol Biol Evol 2008; 25: 912-928

[13] Mikkola ML. TNF superfamily in skin appendage development. Cytokine Growth Factor Rev 2008; 19: 219-230

[14] Pispa J, Mikkola ML, Mustonen T et al. Ectodysplasin, Edar and TNFRSF19 are expressed in complementary and overlapping patterns during mouse embryogenesis. Gene Expr Patterns 2003; 3: 675-679

[15] Keller JP. Hormon- und Fertilisationsstörungen in der Gynäkologie. 4. Aufl. Berlin, Heidelberg: Springer; 2013

[16] Pötzsch O. Statistisches Bundesamt, Wiesbaden - Geburtentrends und Familiensituation in Deutschland. 2013. Online: https://www.destatis. de/DE/Publikationen/Thematisch/Bevoelkerung/HaushalteMikrozensus/ Geburtentrends5122203129004.pdf; last access: 12.12.2016

[17] Przyrembel H; Bundeszentrale für gesundheitliche Aufklärung - Stillen und Muttermilchernährung. Grundlagen, Erfahrungen und Empfehlungen. 2001. Online: http://www.kinderumweltgesundheit.de/index2/ pdf/themen/Allergien/60052_1.pdf; last access: 12.12.2016

[18] Jagfeld EP. Anatomie und Physiologie der weiblichen Brust. In: Jagfeld EP, Hrsg. Frauenheilkunde natürlich - Das Fachbuch für die Praxis. Norderstedt: Books on Demand GmbH; 2014: 131

[19] Jackisch C, Schneider HPG. Gutartige Erkrankungen der weiblichen Brust. In: Dudenhausen JW, Schneider HPG, Bastert G, Hrsg. Frauenheilkunde und Geburtshilfe. Berlin: de Gruyter Lehrbuch; 2003: 395-416
[20] Göttlicher S. Über die Häufigkeit und Lokalisation von Polythelien, Polymastien und Mammae aberratae. Geburtsh Frauenheilk 1986; 46: 697699

[21] Schaal B, Doucet S, Sagot P et al. Human breast areolae as scent organs: morphological data and possible involvement in maternal-neonatal coadaptation. Dev Pyschobiol 2006; 2: 100-110

[22] Doucet S, Soussignan R, Sagot $P$ et al. The secretion of areolar (Montgomery's) glands from lactating women elicits selective, unconditional responses in neonates. PLoS One 2009; 4: e7579

[23] Schwegler U, Kohlhuber M, Twardella D et al. Einfluss der Stillbedingungen in den ersten Lebenstagen auf die Dauer des ausschließlichen Stillens. Geburtsh Frauenheilk 2008; 68: 607-614

[24] Dos Santos CO, Dolzhenko E, Hodges E et al. An epigenetic memory of pregnancy in the mouse mammary gland. Cell Rep 2015; 11: 11021109

[25] Jacobs A, Abou-Dakn M, Becker K et al. S3-Leitlinie „Therapie entzündlicher Brusterkrankungen in der Stillzeit", AWMF Leitlinien-Register Nr. 015/071 (Kurzfassung). Geburtsh Frauenheilk 2013; 73: 1-7

[26] Hernandez Yenty QM, Jurgens WJ, van Zuijlen PP et al. Treatment of the benign inverted nipple: a systematic review and recommendations for future therapy. Breast 2016; 29: 82-89

[27] Jeong HS, Lee HK. Correction of inverted nipple using subcutaneous turn-over flaps to create a tent suspension-like effect. PLoS One 2015; 10: e0133588 